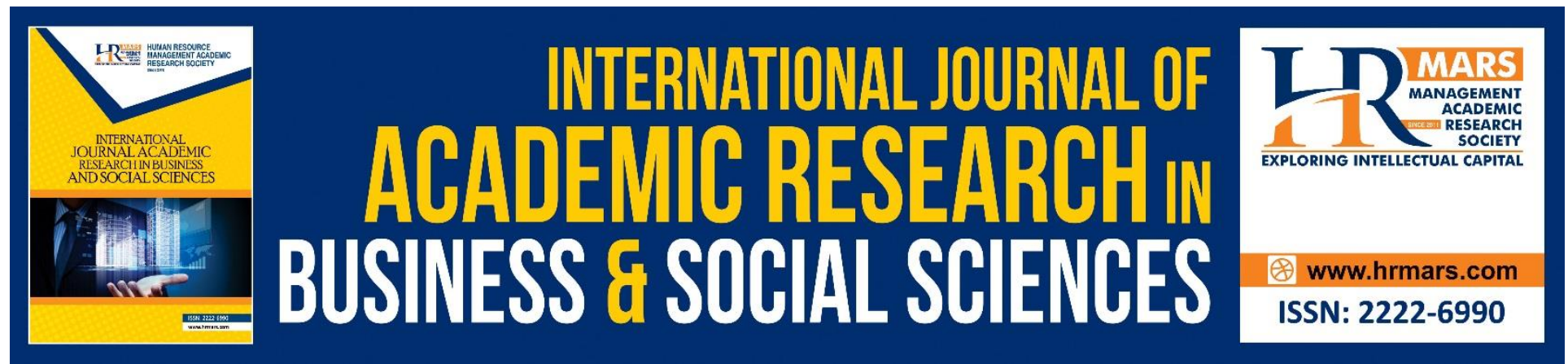

\title{
Exploring Predictors of Gen Z Working Environment in Malaysia: A Case Study on a Group of Private Colleges
}

Mas Anom Abdul Rashid, Amran Rasli, Mohd Noor Azman bin Othman, Ida Rosnita Ismail, Zainurin Abdul Rahim, Ruhil Amani Said

To Link this Article: http://dx.doi.org/10.6007/IJARBSS/v11-i3/8985 DOI:10.6007/IJARBSS/v11-i3/8985

Received: 04 February 2021, Revised: 27 February 2021, Accepted: 06 February 2021

Published Online: 16 March 2021

In-Text Citation: (Rashid et. al., 2021)

To Cite this Article: Rashid, M. A. A., Rasli, A., Othman, M. N. A. bin., Ismail, I. R., Abdul Rahim, Z., \& Said, R. A. (2021). Exploring Predictors of Gen Z Working Environment in Malaysia: A Case Study on a Group of Private Colleges. International Journal of Academic Research in Business and Social Sciences, 11(3), 836850.

Copyright: (c) 2021 The Author(s)

Published by Human Resource Management Academic Research Society (www.hrmars.com)

This article is published under the Creative Commons Attribution (CC BY 4.0) license. Anyone may reproduce, distribute, translate and create derivative works of this article (for both commercial and non-commercial purposes), subject to full attribution to the original publication and authors. The full terms of this license may be seen

at: http://creativecommons.org/licences/by/4.0/legalcode

Vol. 11, No. 3, 2021, Pg. 836 - 850

http://hrmars.com/index.php/pages/detail/IJARBSS

JOURNAL HOMEPAGE

Full Terms \& Conditions of access and use can be found at http://hrmars.com/index.php/pages/detail/publication-ethics 


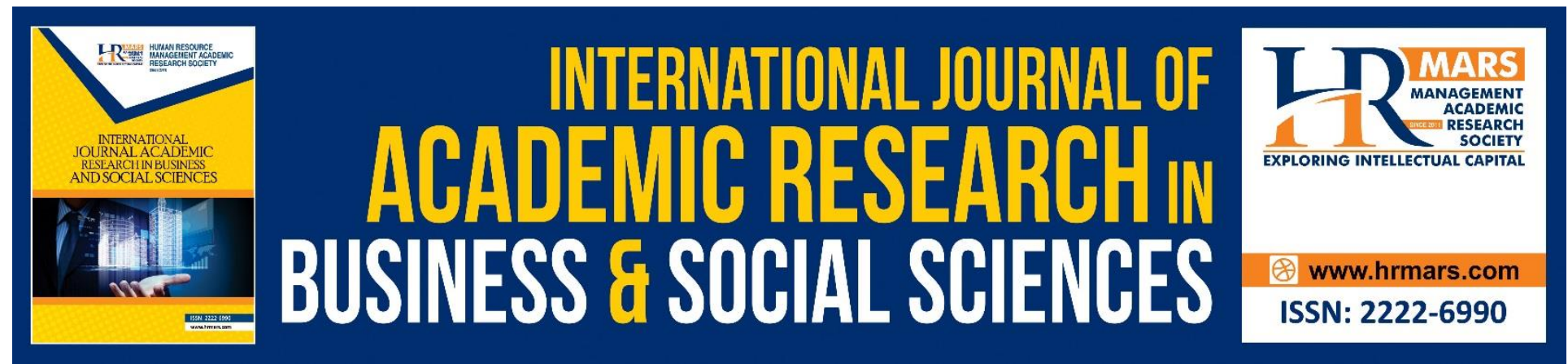

\title{
Exploring Predictors of Gen Z Working Environment in Malaysia: A Case Study on a Group of Private Colleges
}

\author{
Mas Anom Abdul Rashid \\ Faculty of Business, Accounting, and Social Science \\ Email: masanom@kuptm.edu.my \\ Amran Rasli \\ SUMAIT University, Zanzibar, Kolej Universiti Poly-Tech MARA \\ Email:m-amran@utm.my \\ Mohd Noor Azman bin Othman \\ Faculty of Computer and Multimedia, Kolej Universiti Poly-Tech MARA \\ Email: n.azman@kuptm.edu.my \\ Ida Rosnita Ismail \\ Graduate School of Business, UKM \\ Email: idarosnita@ukm.edu.my

\section{Zainurin Abdul Rahim} \\ Faculty of Business, Accounting, and Social Science, College University Poly-Tech MARA Kuala \\ Lumpur, Malaysia.

\section{Ruhil Amani Said} \\ Institute of Graduate Studies College University Poly-Tech MARA Kuala Lumpur, Malaysia.
}

\section{Abstract}

In order for an organization to stay competitive in its core business, the workforce has to be formed from a group of people who happy, satisfied and focus on the task entrusted to them. Therefore it is paramount to makesure that the working environment the employers prepare for the workforce has to be of their preferences and expectation. Understanding the humanistic requirements of the future workforce who are technological incline is very important to help 
retain them in the organization. The development of improved technology has pushed the boundaries of human expectation to another level that place the employers to be well prepared for the newer generation which is starting to take their places in the working world. This genenration is non other than Gen Z. Labelled as " the always connected generation", this generation will definitely have their expectation of the future work environment in order to maintain them in the office. The purpose of this analysis is to examine the response of 347 students from a group of private colleges who are Gen-Z born in 1995 to 2000 in an effort to conceptualize the preferred future working environment that will suit and retain them. The Smart Partial Least Square (Smart PLS) study shows a close relationship between characteristics, preferred communication, preferred leadership, expectation towards the working environment, towards their expected working environment. This study introduces significant results with implications for both practical methods and analytical analysis.

\section{Introduction}

History has shown that when a new generation enters the workforce, it often prompts comparisons to those who came before and much anticipation and predictions on how the age could impact the workforce. As an example, the Millennial (those born between 1981-1994) were prone to introduce new forms of communication and prioritize the social responsibility of their employers (Ferri-Reed, 2016), while demonstrating less loyalty to the organizations they serve (Deloitte, 2016) as compared to their predecessor Gen X (those born between 1965-1980). Further, Buckley, Venieke, and Barua (2016) suggested the shifting behavioral patterns of the Millennial are attributed to their higher levels of college debt and delayed family planning as well as the past economic recession.

As generations evolve, from baby boomers to Gen $X, Y$ (or Millennials), and now Gen Z, the demographics of a country pose significant challenges not only for local but also for multinational organizations. The arrival of Gen Z is no different, as evident by most studies that focus on the impact that omnipresent personal technology has had on society (Stahl, 2017; Patel, 2017). Hence, many have speculated about how much influence an "always-connected generation" will have on the workplace. For example, in a study of 4,000 Gen Z participants, $92 \%$ are concerned about the generational gap technology is causing in their professional and personal lives (Stillman \& Stillman, 2017).

In another research, another 37 percent expressed concern that technology weakens their ability to maintain strong interpersonal relationships and develop people skills (O'Boyle, Atack and Monahan, 2017). In contrast, these digital natives may bring an unprecedented level of technology skills to the workforce, some apprehensions about their ability to communicate and form strong interpersonal relationships with others.

Malaysians do not have much literature on Gen Z except for some studies by Mohd Sharil, Nur Nazuha, and Nik Sulaiman (2017) on Generation Z behavioural characteristics and its effect on hostel facility. Besides, the LinkedIn Opportunity Index 2020 survey of 30,000 respondents from 22 countries, including Malaysia and the USA, showed that the biggest skill gaps seen today are soft skills among Gen Z and Millennials and tech skills among the older generation (Ram, 2020). Finally, a recent study by Ng, Ho, Lim, Chong, and Latiff (2019) provides some ideas on Gen-Z consumers' value, emphasizing functional importance, fun value, and value for money when adopting smart retailing technology. As per past studies, the authors also believe that technology 
has weakened the ability of Gen Z to maintain strong interpersonal relationships and develop people skills; therefore, the need to acquire these skills to adapt to the workforce.

\section{Characteristics of Generation Z}

MacKenzie, McGuire, and Hartwell (2012), Glass (2007), and Wiedmer (2015) postulate that there are five categories of generations from 1900 till now (refer to Table 1). Every generation has a different set of experience which influenced their behavior and attitude in lives. Previous research has proven that different generations have a different approach in tackling their working lives; thus, setting the work culture at that particular point in time. For example, Stillman and Stillman (2016) and Ferri-Reed (2016) suggests that employers have to understand the different generations, i.e., Gen X, Y, and Z, as their preference and matters of importance are different.

Therefore, to ease future planning and development activities and the success of organizations in Malaysia, the authors believed that employers need to understand Gen Zers as they enter the workforce today. More will be the dominant workforce of the future. Further, Gen Zers are also known as the "Net Gen" generation who have embraced information technology and the internet to the max.

According to Wiedmer (2015), Gen $Z$ is the latest generation currently growing up and will be dominating the world in the next decades. Gen $Y$, also termed as Millennials, are logically the biggest group in any workforce. On the other hand, Gen $Z$ is the tweens, the youngsters, the adolescent, and youthful grown-ups of our worldwide society. Gen $Z$ has been naturally introduced to the emergency time of psychological warfare, terrorism, the worldwide retreat, and environmental change. They are the early adopters, the brand influencers, the internetbased life drivers, the popular culture pioneers. They will be the dominant group shortly, and they don't simply speak to what is coming; they are making it.

Table 1: Dominant Characteristics of Generations

\begin{tabular}{|c|c|c|}
\hline Generation & $\begin{array}{c}\text { Range of Birth } \\
\text { Year }\end{array}$ & $\begin{array}{c}\text { Dominant Behavioural } \\
\text { Characteristics }\end{array}$ \\
\hline Traditionalists & $1900-1945$ & Loyal and disciplined \\
\hline Baby Boomers & $1946-1964$ & $\begin{array}{c}\text { Responsible, strong work } \\
\text { ethics }\end{array}$ \\
\hline Generation X & $1965-1980$ & $\begin{array}{c}\text { Independent thinkers, } \\
\text { efficient }\end{array}$ \\
\hline Generation Y & $1981-1994$ & $\begin{array}{c}\text { More social, confident, } \\
\text { less independent }\end{array}$ \\
\hline Generation Z & $1995-2012$ & $\begin{array}{c}\text { Poor communication } \\
\text { skills, extensively } \\
\text { engaged in technology }\end{array}$ \\
\hline
\end{tabular}

Source: MacKenzie, McGuire, and Hartwell (2012), Glass (2007) and Wiedmer (2005)

Previous researchers have shown that Gen $Z$ is different from the Millennials such as reported by Ernst \& Young (2016) in a survey of 3,200 Gen Z in Brazil, China, Germany, India, Japan, Mexico 
and UK, and the US indicated that Gen Z value employers that provide equal opportunity for pay and promotion, opportunities to learn and advance professionally. They also reported that Gen $Z$ prefers employers who treat people with respect, ethical behavior, fair compensation and promotion, open and transparent communication, and wise business decision-making. However, $11 \%$ of global respondents, including $18 \%$ from the US, indicated that their caretakers' work experience had a "very or somewhat negative" impact on the level of trust they would place in future employers. They also include that low quality of raises, a dislike of job, or dislike or distrust of boss, colleagues, or top-level executives.

Merriman \& Velario (2016) surveyed 1,000 adults and 400 teens to examine their mindset behind changing consumer behavior between millennials and Gen $Z$ on retail consumption and found that different concepts can be applied to the consumption of educational resources. Merriman (2016) also found that Gen Zers desire more personalized micro-experience and feel like "anything is possible." They are also prone to purchase the product online due to ease, efficiency, convenience, better selection, and the lower price (Merriman \& Valerio, 2016).

\section{Problem Statement}

Every generation has a different set of experiences that influence their behavior and attitude in lives, especially at the workplace. The authors believe that the expectations, characteristics, and traits, preferred communication style, and preferred leadership style could shape the working environment of Gen Zers. According to Stahl (2019), Gen Z wants some form of human element woven into their work and team interactions. This means a workplace needs to provide the technical aspect with a twist of human connection. Gen Z does not only value frequency with feedback, but they also value measurability based on a technology portal that can track, or even trend, their performance.

A study by Patel (2017) identified certain leadership traits favored by Gen Z. Gen Z are appreciative of organization leaders who can provide a work environment that promotes inclusivity, curiosity, self-motivation, generosity, and perseverance. Additionally, Gen Z wants mentorship and understands that working for leaders who are willing to talk about their paths will allow them to forge mentor-mentee relationships that may last for the entirety of their careers.

\section{Problem Statement}

Nowadays, most organizations would comprise of employees from Baby Boomers, Gen X, Gen $Y$, and Gen Z. According to Fry (2018), Gen Zers are the largest generation in the U.S. labor force, the same pattern is expected to be global, including Malaysia.

The Media Ecology Theory postulated that media affects the progression of society, and significant changes across time are driven by the rise of technology during that period (McLuhan, 1967). Since the introduction of mass print media in pre-telephony time, it has been noted its power to drive people's behavior. Ong (1982) further improved the media ecology theory and suggested that the way people think had fundamentally changed when writing was able to be mass reproduce through print. Recent development indicates that as the internet further penetrates all spheres of society, the metaphor of the ecosystem could serve as a metaphor for society and not only for the economy (Ruotsalainen and Heinonen, 2015). Ruotsalainen, J. and Heinonen, S. (2015) believe that different areas of society, such as private and public, work, and 
leisure time and various institutions and organizations, will begin to interlock as a consequence of the spread of electronic and digital media. In this environment, Gen Zers will thrive as compared to the others. The evolution of media - print, radio, TV, telephony, and now the age of the internet and social web, are significant technological milestones that have changed people's thinking and behavior, especially the Gen Zers, as shown in Figure 1.

Figure 1: Key milestones in media evolution

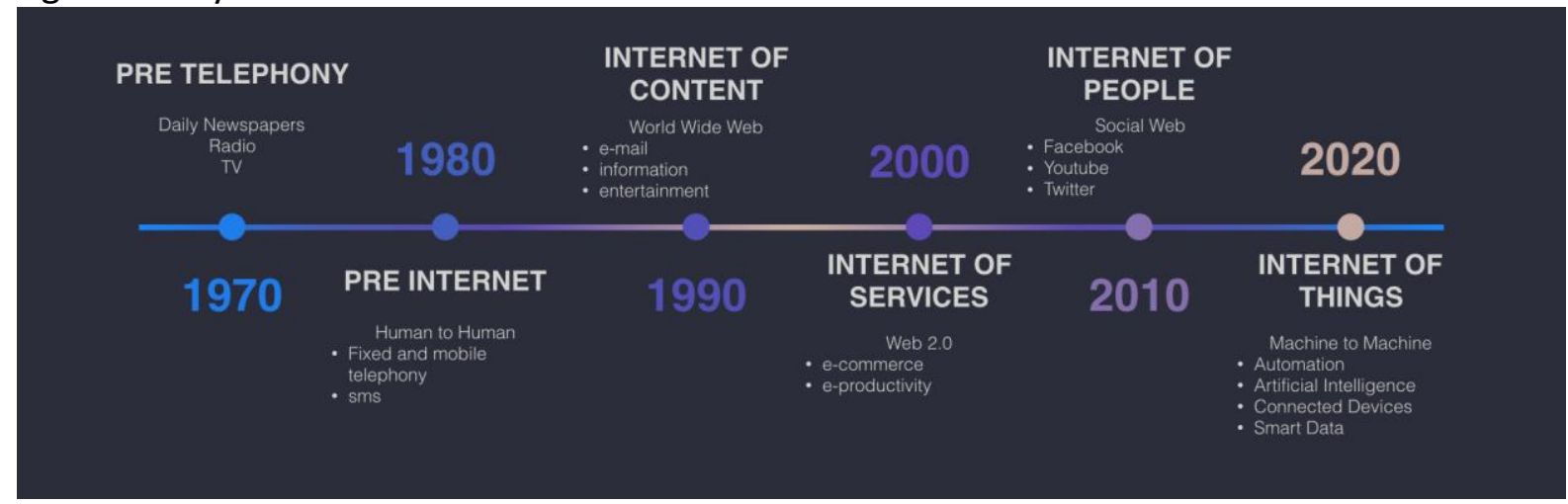

Source: Tan (2018)

As such, this study seeks to provide more understanding of Gen Zers' needs and expectations in their working life and provide employers with the knowledge to prepare themselves on what to expect in terms of planning, leadership style, workplace environment, and communication. The study also hopes to close the gap in the literature and provide more knowledge of Gen $Z$ in Malaysia.

\section{Research Objectives}

This study seeks to determine the relationship between Gen Z needs and expectations, characteristics and traits, preferred communication style, preferred leadership style, and work environment. Besides, this study seeks to compare the features mentioned above based on gender. The research site of this study is at $A B C D$ Colleges.

\section{Methodology}

This exploratory study was conducted among students of one of the biggest groups of private colleges in Malaysia. A questionnaire was developed based on the adaptation of articles written by Singh (2014), Agarwal and Vaghela (2017), as well as Singh and Dangmei (2016). Several selfdeveloped items were included to ensure the questionnaire is reflective of the work environment in Malaysia. A pilot study was carried out among $15 \mathrm{MBA}$ and Ph.D. students at the main campus of the college to identify the potential error to improve the reliability and validity of the research questionnaire. The questionnaire was then content validated by three professors from a renowned university who are experts in demography and organizational behavior. In conducting the research, the authors used a convenience sampling method, as this is an exploratory study. The data were collected from the 5 ABCD Colleges through Google docs. Care was taken to avoid accepting respondents who are more than 25 years old as they will not be classified as a Gen Z. Finally, in addition to descriptive analyses, statistical techniques such as correlational analysis 
and Mann Whitney $U$ used to measure the correlation and difference of means respectively. Statistical package for the social sciences (SPSS) and SmartPLS were used to analyze collected data, respectively.

\section{Analysis}

Descriptive Analyses, Structural Equation Modelling, and Mann Whitney U Tests were performed to the data collected. Altogether, data obtained from 327 respondents were deemed usable for subsequent analyses.

\section{Descriptive Analyses}

Descriptive analyses were performed for the demographic items used in the survey questionnaire. Based on Table 2, most of the respondents are males (64\%), Malays (90.8\%), aged between 23 - 25 years old (48.5\%), single (92.9\%), from Selangor (21.1\%). The number of students who has STPM (or A level equivalence) education qualification (25.5\%). Most of them are doing their bachelor degree. Based on the statistics mentioned above, the authors conclude that the sample collected portrays a fair representation of the population of the students at the private colleges as these institutions are new. The next most significant education level is the certificate level program (24.6\%), which is the CAT (Certified Accounting Technician) students who are doing a professional program, ACCA (the Association of Chartered Certified Accountant) followed by students from the bachelor degree program (21.6\%).

Table 2: Demographic Background of Respondents

\begin{tabular}{|c|c|c|}
\hline Demography & Number & Percentage \\
\hline Gender & 123 & 36.4 \\
$-\quad$ Male & 215 & 63.6 \\
\hline Race & & \\
- Malay & 307 & 90.8 \\
- Chinese & 22 & 6.5 \\
- Indian & 6 & 1.8 \\
- Others & 3 & 0.9 \\
\hline Marital Status & & \\
- Single & 314 & 92.9 \\
- Married & 24 & 7.1 \\
\hline Years of working experience & & \\
- Less than one year & 251 & 74.3 \\
- 1-2 year & 51 & 15.1 \\
- 2 to 3 years & 17 & 5.0 \\
- More than three years & 19 & 5.7 \\
\hline Education Level & & \\
- STPM/A level & 86 & 25.5 \\
- Certificate & 83 & 24.6 \\
- Diploma & 92 & 62.4 \\
- Bachelor Degree & 73 & 21.6 \\
- Master Degree & 4 & 1.2 \\
\hline
\end{tabular}


Structural Equation Modelling

Data obtained from 327 respondents were analyzed using partial least squares structural equation modeling (PLS-SEM). This second-generation data analysis technique was suitable for the present study because it allows the formative measurement model to be assessed (Hair et al., 2017). SmartPLS 3 was used as an exploratory study (Ringle, Wende $\&$ Becker, 2015). Based on Figure 2, three constructs: characteristics, preferred communication, and preferred leadership, were modeled formatively. Besides, using SmartPLS 3 allows the researchers to account for the unique contribution of every manifest variable to the model estimation instead (Hair et al., 2017).

The assessment of a PLS model follows the two-stage approach (Hair et al., 2017). At the first stage, the measurement model was assessed to establish its reliability and validity. Once the objective was achieved, then the assessment proceeds with evaluating the structural model. The assessment criteria for the measurement model differ according to its type. Whereas the reflective measurement model is assessed by examining indicator loading, indicator reliability, internal consistency reliability, convergent validity, and discriminant validity, the formative measurement model is evaluated by examining convergent validity, variance inflation factor (VIF) as outer weights and significance. The standard assessment criteria for a structural model include examining the coefficient of determination $\left(R^{2}\right)$, effect size $\left(f^{2}\right)$, magnitude and significance of path coefficients, and out-of-sample predictive relevance $\left(Q^{2}\right)$.

Table 3 shows the results for the reflective measurement model assessment involving constructs expectation (EXPE) and working environment (WOEN). Six of the indicator loadings surpassed the threshold value of 0.707 , and the remaining indicator loadings were within the range $0.548(x 18)$ to $0.696(x 16)$. Although these loadings were below the threshold value, they were retained in the present study given that the composite reliability and average variance extracted were above 0.70 and 0.50 , respectively. The internal consistency reliability was also evidenced by examining the Cronbach's alpha values whereby the values were 0.858 for expectation and 0.713 for the working environment. The discriminant validity was also established with an $\mathrm{HTMT}_{0.85}$ value of 0.847 . This means that the study constructs in the model were distinctive.

Results for formative measurement models are shown in Table 4. Redundancy analysis was run to identify the constructs' convergent validity. The variance inflation factor values for all items were below 5, ranging from 1.090 (x2) to 1.889 (x10), indicating no collinearity issue. Next, the relative contribution of the formative items was assessed. Except for two items, all items in the formative measurement model were significant, with outer weights ranging from $0.182(x 7)$ to $0.611(x 5)$. Following Hair et al.'s (2017) suggestion, the outer loadings for $x 6$ and $x 9$ were assessed. In both cases, the outer loadings were above 0.50; hence, the two items were retained in this model. 
INTERNATIONAL JOURNAL OF ACADEMIC RESEARCH IN BUSINESS AND SOCIAL SCIENCES

Vol. 11, No. 3, 2021, E-ISSN: 2222-6990 @ 2021 HRMARS

Table 3. Reflective measurement model results

\begin{tabular}{|c|c|c|c|c|c|c|c|}
\hline Construct & Item & & $\begin{array}{l}\text { Outer } \\
\text { loadings }\end{array}$ & $\begin{array}{l}\text { Indicator } \\
\text { Reliability }\end{array}$ & $\begin{array}{l}\text { Cronbach's } \\
\text { alpha }\end{array}$ & $\begin{array}{c}\text { Composit } \\
\text { e } \\
\text { reliability }\end{array}$ & $\begin{array}{l}\text { Average } \\
\text { variance } \\
\text { extracted }\end{array}$ \\
\hline \multirow[t]{9}{*}{ EXPE } & $x 11$ & $\begin{array}{l}\text { Work environment develop potential } \\
\text { Develop meaningful relationship in }\end{array}$ & 0.791 & & 0.858 & 0.89 & 0.506 \\
\hline & $x 12$ & workplace & 0.723 & & & & \\
\hline & $x 13$ & $\begin{array}{l}\text { Value desire to grow and develop naturally } \\
\text { Well-being reflected ability to work }\end{array}$ & 0.812 & & & & \\
\hline & $x 14$ & competently & 0.773 & & & & \\
\hline & $\mathrm{x} 15$ & Like intangible rewards & 0.641 & & & & \\
\hline & x16 & Like to be given authority when doing work & 0.696 & & & & \\
\hline & $x 17$ & Like to plan own career development & 0.667 & & & & \\
\hline & $\mathrm{x} 18$ & Work better if get higher pay & 0.548 & & & & \\
\hline & & View professional development as top & & & & & \\
\hline \multirow[t]{5}{*}{ WOEN } & y1 & priority & 0.679 & & 0.713 & 0.822 & 0.538 \\
\hline & & Cultivated work ethics to increase & & & & & \\
\hline & y2 & $\begin{array}{l}\text { productivity } \\
\text { Geographical setting and time zone not }\end{array}$ & 0.775 & & & & \\
\hline & y3 & barriers & 0.642 & & & & \\
\hline & y4 & Community friendly organization & 0.823 & & & & \\
\hline
\end{tabular}

Note. EXPE = expectation, WOEN = working environment 
INTERNATIONAL JOURNAL OF ACADEMIC RESEARCH IN BUSINESS AND SOCIAL SCIENCES

Vol. 11, No. 3, 2021, E-ISSN: 2222-6990 @ 2021 HRMARS

Table 4. Formative measurement model results

\begin{tabular}{lllccccc}
\hline Construct & Item & & VIF & $\begin{array}{c}\text { Outer } \\
\text { weight }\end{array}$ & Sig. & $\begin{array}{c}\text { Outer } \\
\text { loading }\end{array}$ & Sig. \\
\hline CHAR & x1 & Realistic and optimistic & 1.236 & 0.597 & 0.000 & 0.849 & 0.000 \\
& x2 & Voice to be heard & 1.090 & 0.409 & 0.000 & 0.628 & 0.000 \\
& x3 & Self-reliance & 1.154 & 0.370 & 0.000 & 0.641 & 0.000 \\
PRCO & x4 & Prefer good environment & 1.292 & 0.553 & 0.000 & 0.843 & 0.000 \\
& x5 & Allow to respond & 1.292 & 0.611 & 0.000 & 0.874 & 0.000 \\
PRLE & x6 & Honest leadership & 1.614 & 0.182 & 0.061 & 0.711 & 0.000 \\
& x7 & Transparency & 1.253 & 0.272 & 0.006 & 0.627 & 0.000 \\
& x8 & Develop talents & 1.691 & 0.365 & 0.000 & 0.823 & 0.000 \\
& x9 & Give recognition & 1.588 & 0.193 & 0.081 & 0.701 & 0.000 \\
& x10 & Freedom to share opinion & 1.889 & 0.330 & 0.003 & 0.802 & 0.000 \\
\hline
\end{tabular}

Note. CHAR = characteristic, $\mathrm{PRCO}=$ preferred communication, $\mathrm{PRLE}=$ preferred leadership

The first stage assessment clearly shows that reliability and validity for the measurement models were established. Therefore, structural model was assessed at the second stage using the assessment criteria as outlined previously. First, collinearity was assessed by examining the variance inflation factor values. In the present structural model, no collinearity issue was detected because all variance inflation factor values for the constructs were less than 5 . Next, the coefficient of determination, $R^{2}$, was assessed.

Given that the $R^{2}$ value was $0.528,52.8$ percent of the variance in the endogenous latent variable was explained by the four predictors. Although there was no large effect size for the four predictors, the expectation has a nearly medium effect size $\left(f^{2}=0.148\right)$ compared to the other three predictors. The lowest effect size was for preferred leadership $\left(f^{2}=0.017\right)$, which means that this construct does not affect the endogenous construct using the current sample. Next, the out-of-sample predictive relevance was assessed using two procedures: blindfolding procedure and PLS predict procedure. Results show $Q^{2}$ values were 0.273 and 0.495 , respectively, which indicates that the model has good predictive relevance. 
INTERNATIONAL JOURNAL OF ACADEMIC RESEARCH IN BUSINESS AND SOCIAL SCIENCES

Vol. 11, No. 3, 2021, E-ISSN: 2222-6990 ๑ 2021 HRMARS

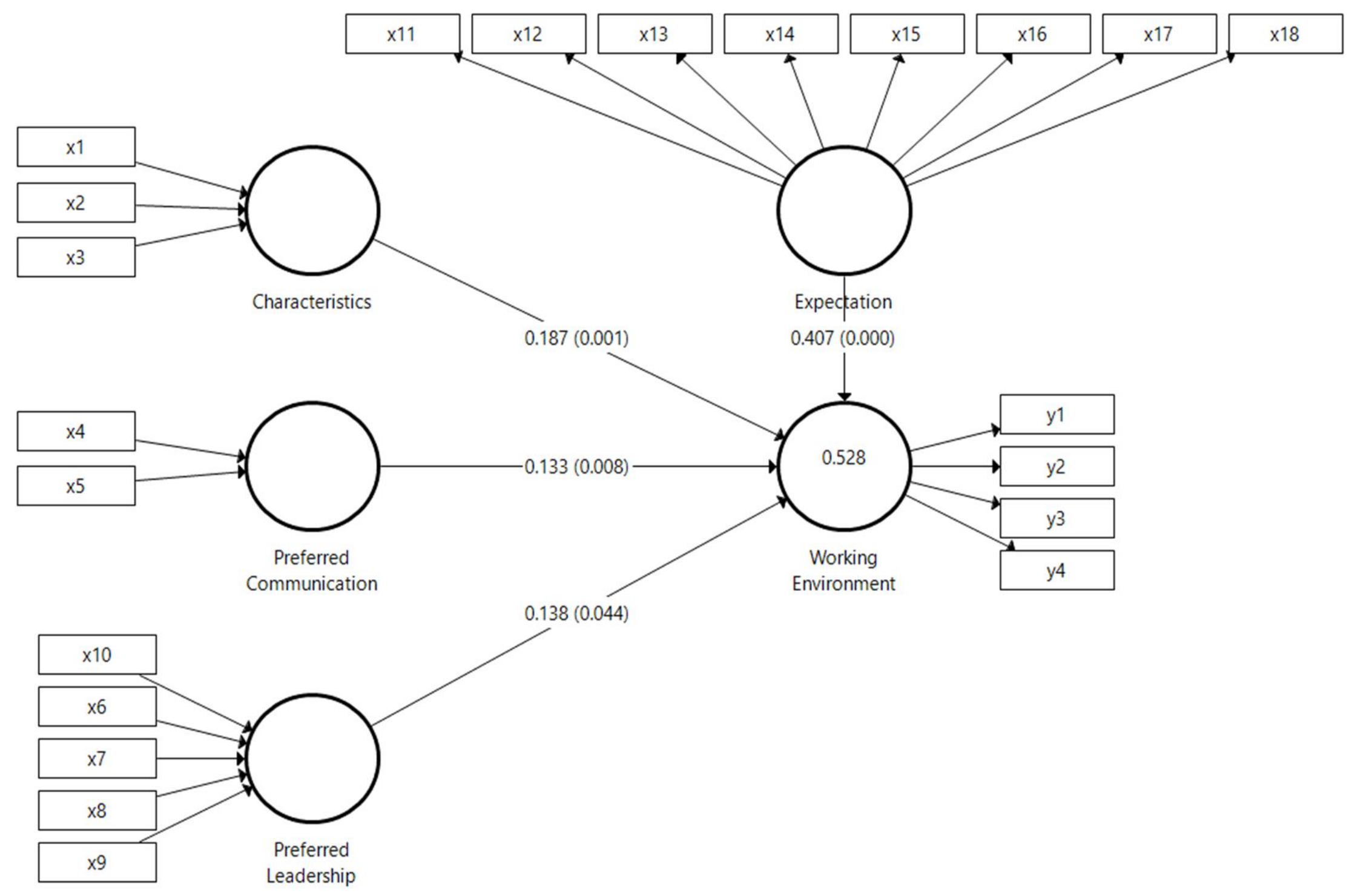

Figure 2. Structural model result 
Mann Whitney U Tests

As data are ranked or ordinal, the Mann Whitney $U$ tests are appropriate to compare the levels of expectations, characteristics and traits, preferred communication style, preferred leadership style, and work environment based on the gender of the respondents. A series of null hypotheses were developed as follows:

Ho1: the mean ranking of Character (MChar) is the same for males and females Ho2: the mean ranking of Expectation (MExpect) is the same for males and females Ho3: the mean ranking of Preferred Communication (MComm) is the same for males and females

Ho4: the mean ranking of Preferred Leadership (MLead) is the same for males and females Ho1: the mean ranking of Work Environment (MWorkEnv) is the same for males and females The results of the Mann Whitney $U$ Tests are presented in Table 5.

Table 5: Mann Whitney U Tests on Key Constructs

\begin{tabular}{|c|c|c|c|c|c|}
\hline \multicolumn{5}{|c|}{ Ranks } & \multirow[t]{2}{*}{ Test Statistics } \\
\hline & Gender & $\mathrm{N}$ & Mean Rank & Sum of Ranks & \\
\hline \multirow[t]{3}{*}{ Mchar } & Female & 123 & 176.87 & 21755.00 & Mann Whitney: 12316 \\
\hline & Male & 215 & 165.28 & 35536.00 & Z score -1.051, $p$-value: 0.157 \\
\hline & Total & 338 & & & Decision: Fail to reject Ho \\
\hline \multirow[t]{3}{*}{ Mcomm } & Female & 123 & 164.20 & 20197.00 & Mann Whitney: 12571 \\
\hline & Male & 215 & 172.53 & 37094.00 & Z score $-0.766, p$ value: 0.222 \\
\hline & Total & 338 & & & Decision: Fail to reject Ho \\
\hline \multirow[t]{3}{*}{ Mlead } & Female & 123 & 168.02 & 20667.00 & Mann Whitney: 13041 \\
\hline & Male & 215 & 170.34 & 36624.00 & Z score $-0.211, p$ value: 0.833 \\
\hline & Total & 338 & & & Decision: Fail to reject Ho \\
\hline \multirow[t]{3}{*}{ MExpect } & Female & 123 & 181.47 & 22320.50 & Mann Whitney: 11750.50 \\
\hline & Male & 215 & 162.65 & 34970.50 & Z score $-1.707, p$ value: 0.044 \\
\hline & Total & 338 & & & Decision: Reject Ho \\
\hline \multirow[t]{3}{*}{ MWorkEnv } & Female & 123 & 183.71 & 22596.00 & Mann Whitney: 11475 \\
\hline & Male & 215 & 161.37 & 34695.00 & Z score $-2.025, p$ value: 0.022 \\
\hline & Total & 338 & & & Decision: Reject Ho \\
\hline
\end{tabular}

\section{Discussion and Recommendations}

The descriptive analyses show that the sample collected is representative of the population parameters. The finding of the study shows that the young Gen Z from this private colleges shows that their expectations; characteristics and traits; preferred communication style preferred leadership style are all positively and significantly related to work environment with $p$-values less than 0.05 . The expectation has the highest correlation coefficient of 0.407 , while preferred communication is the lowest at 0.133 . This finding is consistent with a study by Olanipekun (2017) that indicates organizations should provide an employee with a cordial environment that complies with employees' expectations from the job. According to Gerst (2013), communication between managers and employees is a significant driver of employee engagement as disengaged employees often do not perceive their direct managers as effective communicators (Neves \& Eisenberger, 2012). Cummings et al. (2018) further attest to the importance of leadership styles and outcome patterns in a work environment based on the outcome of an extensive literature review. 
The Mann Whitney $U$ tests results indicate that two hypotheses are significant, i.e., work expectation and work environment are different based on gender, whereby females have lower levels of agreement to the measures of both constructs as compared to males. The first finding of the Mann Whitney $U$ tests is consistent with a study by Miller and Katz (2018) where female participants from the medical sector perceived more gender-based discrimination at work, i.e., perceptions of workplace discrimination may contribute to the persistence of the gender gap. However, the second finding contrasts with the results of a study by Jaworek and Dyląg (2015) that shows statistically significantly higher levels of all three examined job engagement (i.e., absorption, dedication, vigor) in women compared to men.

Based on the first conclusion, the authors recommended $A B C D$ Colleges to implement Örtenblad's (2013) plans for their Gen Z workforce to become knowledge workers in a learning organization. Firstly, $A B C D$ Colleges should encourage learning at work, i.e., learning occurs while the work is being performed. Secondly, it is to plan for organizational learning where employees are encouraged to master single-loop learning and to enable double-loop learning to evaluate what is doing. Thirdly is to create a climate for learning where employees are facilitated for learning by taking risks. Finally, it is to develop a learning structure in a flexible and organic organization, which provides autonomy, decentralization, empowerment, continuous learning, and a non-hierarchical structure. The authors believe that a combination of Senge's (1990) systematic view and Örtenblad's $(2002,2013)$ practical perspective would be an ideal way to implement the process and development of learning organization at $A B C D$ Colleges. To effectively implement the plans mentioned above, leadership at $A B C D$ Colleges needs to practice more people management skills and implement an equal opportunity policy for all employees to avoid gender biases to create a sense of belonging among the Gen Zers.

Since this is an exploratory study, the authors recommend other researchers to expand the findings of this study by doing a comparative analysis across institutions and sectors. Finally, an in-depth qualitative analysis could uncover more meaningful insights into the perceptions of Gen Z of the workplace.

\section{References}

Agarwal, H., \& Vaghela, P.S. (2018). Work Values of Gen Z: Bridging the Gap to the Next Generation. National Conference on Innovative Business Management Practices in 21st Century 21-22 December, 2018.

Buckley, P., Viechnicki, P., \& Barua, A. (2015). A new understanding of millennials: Generational differences reexamined. Deloitte. Retrieved from https://www2.deloitte.com/insights/us/en/economy/issues-by-the-numbers/ understanding-millennials-generational-differences.html

Christensen, C. M., \& Henry J. E. (2011). The Innovative University: Changing the DNA of Higher Education from the Inside out, San Francisco, CA: Jossey-Bass.

Cummings, G. G., Tate, K., Lee, S., Wong, C. A., Paananen, T., Micaroni, S. P. M., \& Chatterjee, G. E. (2018). Leadership styles and outcome patterns for the nursing workforce and work environment: A systematic review. International Journal of Nursing Studies. doi: 10.1016/j.ijnurstu.2018.04.016. Epub 2018 May 3. PMID: 29807190.

Ferri-Reed, J. (2016). Know Your XYZs: Understanding and harnessing multigenerational talent Quality Progress: Milwaukee, 49(3), pp. 18-23. 
Fry, R. (2018). Millennials are the largest generation in the U.S. labor force. Pew Research Center. Retrieved from https://www.pewresearch.org/facttank/2018/04/11/millennials-largest-generation-us-labor-force/

Gerst, R. (2013). Understanding employee engagement and trust: The new math of engagement surveys. The Journal for Quality and Participation, 35(4), pp. 32-36.

Glass, A. (2007). Understanding generational differences for competitive success. Industrial and Commercial Training, 39(2), 98-103.

Hair, J. F. Jr., Hult, G. T. M., Ringle, C. M., Sarstedt, M. (2017). A Primer on Partial Least Squares Structural Equation Modeling (PLS-SEM), 2nd ed., Thousand Oaks, CA: Sage.

Jaworek, M., Dylag, A.M. (2015). Perception of work environment among women and men workload and autonomy in relation to job engagement. Jagiellonian Journal of Management 1(3), 155-174.

MacKenzie, J., McGuire, R., \& Hartwell, S. (2012). The First Generation of the 21st Century: An introduction to the Pluralist Generation by Magid Generational Strategies. Retrieved from

https://static1.squarespace.com/static/56d7388222482e1e2c87c683/t/56e0cdc2cf8 0a14684670194/1457573327672/ MagidPluralistGenerationWhitepaper.pdf

Sharil, M. S., Nazuha, N. M., \& Nik Sulaiman, B. (2017). Overview of "Generation Z" Behavioural Characteristic and its Effect Towards Hostel Facility. International Journal of Real Estate Studies, 11(2), 59-67.

Merriman, M. (2015). What if the Next Big Disruptor Isn't a What but a Who? Ernst \& Young. Retrieved from http://www.ey.com/Publication/vwLUAssets/ EY-rise-of-gen-znewchallenge-forretailers/\$FILE/EY-rise-of-gen-znewchallenge-for-retailers.pdf

Merriman, M., \& Valerio, D. (2016). One Tough Customer: How Gen Z is Challenging the Competitive Landscape and Redefining Omnichannel. Ernst \& Young Report. Retrieved from http://www.ey.com/Publication/vwLUAssets/EY-one-tough-customer/\$FILE/ EYonetough -customer.pdf

Miller, J., \& Katz, D. (2018). Gender Differences in Perception of Workplace Experience Among Anesthesiology Residents. The journal of education in perioperative medicine : JEPM, 20(1), E618.

Neves, P., \& Eisenberger, R. (2012). Management communication and employee performance: The contribution of perceived organizational support. Human Performance, 25(5), 452-464.

Ng, S. I., Ho, J. A., Lim, X. J., Chong, K. L., \& Latiff, K. (2019). Mirror, mirror on the wall, are we ready for Gen-Z in marketplace? A study of smart retailing technology in Malaysia, Young Consumers, Vol. ahead-of-print No. ahead-of-print. https://doi.org/10.1108/YC-06-2019-1006

O'Boyle, C., Atack, J., \& Monahan, K. (2017). Generation Z enters the workforce: Generational and technological challenges in entry-level jobs. Deloitte Insight. Retrieved from https://www2.deloitte.com/us/en/insights/focus/technology-and-the-future-ofwork/generation-z-enters-workforce.html\#endnote-14

Olanipekun, L. O. (2017). Work Environment and its Implication On Employees Performance. Unpublished report from Olabisi Onabanjo University, Nigeria

Ong, W. J. (1982). Orality and Literacy: The Technologizing of the Word. London: Routledge.

Örtenblad, A. (2013), 'What do we mean by "learning organization"?, in Anders Örtenblad (ed.), Handbook of Research on the Learning Organization: Adaptation and Context. Cheltenham, UK and Northampton, MA, USA: Edward Elgar Publishing 
Patel, D. (2017). The Top 5 Traits Gen Z Looks For In Leaders. Forbes. Retrieved from https://www.forbes.com/sites/deeppatel/2017/08/27/the-top-5-traits-gen-z-looksfor-in-leaders/\#357b6c78609d

Ram, B. S. (2020). Survey: Malaysians find ageism a barrier to work opportunities. New Straits Times. https://www.nst.com.my/news/nation/2020/02/564843/survey-malaysians-findageism-barrier-work-opportunities

Ringle, C. M., Wende, S., \& Becker, J. M. (2015). SmartPLS 3. Bönningstedt: SmartPLS. Retrieved from http://www.smartpls.com

Ruotsalainen, J., \& Heinonen, S. (2015). Media ecology and the future ecosystemic society. European Journal of Futures Research, 3(1), DOI: 10.1007/s40309-015-00687

Senge, P. M. (1990). The Fifth Discipline: The Art \& Practice of the Learning Organization. New York: Doubleday-Currency

Singh, A. P., \& Dangmei, J. (2016) Understanding the generation Z: the future workforce. South-Asian Journal of Multidisciplinary Studies 3(3), 1-5

Singh, A. (2014). Challenges and Issues of Generation Z. IOSR Journal of Business and Management (IOSR-JBM), 16 (7), pp. 59-63.

Stahl, A. (2019). How Generation-Z Will Revolutionize The Workplace. Forbes. Retrieved from https://www.forbes.com/sites/ashleystahl/2019/09/10/how-generation-z-willrevolutionize-the-workplace/\#6ee25974f537

Stillman, D., \& Stillman, J. (2017). Gen Z Work: How the Next Generation Is Transforming the Workplace. Harper Collins.

Tan, N. J. L. (2018). Adoption and use of social media among digital immigrants in Genting Malaysia Berhad. Unpublished PhD thesis from Asia E University.

Wiedmer, T. (2015). Generation Do Differ: Best Practices in Leading Traditionalists, Boomers and Generations $X, Y$ and Z. The Delta Kappa Gamma Bulletin: International Journal for Professional Educators, 51-58. 